\title{
Bronşektazi Tanılı Hastaların Balgam Kültür Sonuçlarının Hastanede Kalış Süresine Etkisi
}

\section{The Effect of Sputum Culture Results on The Duration of Hospitalization in Patients with Bronchiectasis

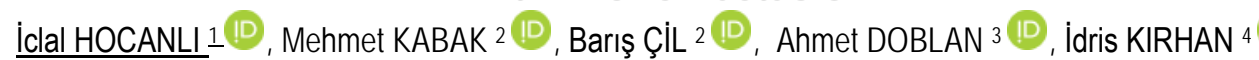

\author{
1Harran Üniversitesi Tıp Fakültesi Göğüs Hastalıkları Anabilim Dalı, Osmanbey Kampüsü, Şanlıurfa/Türkiye \\ 2 Mardin Devlet Hastanesi, Göğüs Hastalıkları Kliniği, Mardin, Türkiye \\ 3 Sağlık Bilimleri Üniversitesi ,Mehmet Akif İnan Sağlık Uygulama ve Araştırma Merkezi, KBB Kliniği, Şanlıurfa, Türkiye \\ 4 Harran üniversitesi Tıp Fakültesi, İç Hastalıkları ABD, Şanlıurfa, Türkiye
}

Öz.

Amaç: Bu çalışmanın amacı, kliniğimizde bronşektazi tanısılla takip edilmiş hastaların balgam kültür sonuçlarının (kültür sonuçlarına göre tedavi revizyonu yapılmasının) hastanede kalış süresi üzerine etkisinin olup olmadığıı araşıırmaktır.

Materyal ve Metod: Ocak 2018- Aralık 2018 tarihleri arasında, göğüs hastalıkları kliniğinde bronşektazi tanısıyla takip edilen 23 hastanın laboratuvar ve radyolojik verileri geriye dönük olarak incelendi. Tüm hastaların demografik özellikleri, hastanede kalış süreleri, kullandıkları antibiyotikler ve kültür sonucuna göre yapılan antibiyotik değişimleri kaydedildi. Kültürde üreme olan ve olmayan hastaların hastanede yatış süreleri karşılaştıııldı. Ek olarak, kültürde üreme olan grup kendi içerisinde üreyen mikroorganizma türüne göre yatış süreleri açısından değerlendirildi.

Bulgular: Hastaların \%39,1'1'nde (9 hasta) kültürde üreme olurken, \%60.9'unda (14 hasta) kültürde üreme olmadı. Dört hastanın kültüründe klebsiella pnömoni, yine dört hastanın kültüründe pseudomonas aeruginosa ve bir hastanın kültüründe de myocobacterium tuberculosis üredi. Hastanede kalış süresi, kültürde üremesi saptanan hastalarda (10.1 $\pm 5,1$ gün) kültürde üremesi saptanmayan hastalara (7.8 $\pm 5,5$ gün) göre daha uzun olmakla beraber istatiksel olarak anlamlı bir farklılık yoktu $(\mathrm{p}=0.135)$. Ancak kültürde üreme olan hastalar mikroorganizma türüne göre karşılaştırılıklarında, psödomonas aeruginosa üremesi olanların hastanede kalış süresilerinin anlamlı olarak daha uzun olduğu görüldü.

Sonuç: Bronşektazi hastalarının balgam kültürlerinde en sık üreyen mikroorganizmalardan biri pseudomonas aeruginosadır. Bu etken, bronşektazili hastaların hastanede yatış sürelerini artırımaktadır.

Anahtar sözcükler: Bronşektazi, Balgam kültürü, Enfeksiyon

\section{Abstract}

Background: The aim of this study is to investigate whether sputum culture results (treatment revision according to culture results) have an effect on the duration of hospitalization in patients who were followed up with the diagnosis of bronchiectasis in our clinic.

Materials and Methods: The laboratory and radiological data of 23 patients who were followed up with the diagnosis of bronchiectasis in the chest diseases clinic between January 2018-December 2018 were analyzed retrospectively. Demographic features, the duration of hospitalization, the used antibiotics and antibiotic changes according to the culture results were recorded for all patients. The duration of hospitalization of patients with and without culture growth was compared. In addition, the culture growing group was evaluated in itself according to the growing microorganism type in terms of the duration of hospitalization.

Results: While $39.1 \%$ (9 patients) of the patients had culture growth, $60.9 \%$ (14 patients) had no culture (14 patients). Klebsiella pneumonia was detected in the culture of 4 patients, pseudomonas aeruginosa in the culture of 4 patients and mycobacterium tuberculosis in the culture of 1 patient. Although the duration of hospitalization was longer in patients with $(10.1 \pm 5.1$ days) than those without culture growth $(7.8 \pm 5.5$ days), there was no significant difference between two groups $(p=0.135)$. However, when patients with culture growth were compared according to the microorganism type; it was detected that patients with pseudomonas aeruginosa growth in the culture had significantly longer duration of hospitalization.

Conclusion: Pseudomonas aeruginosa is one of the most common grow microorganisms in sputum cultures of patients with bronchiectasis. This factor increases the duration of hospitalization of patients.

Key words: Bronchiectasis, Sputum culture, Infection
Sorumlu Yazar I

Corresponding Author

Dr. İclal HOCANLI,

Harran üniversitesi Tıp Fakültesi, Göğüs Hastalıkları ABD,

Şanlıurfa, Türkiye

E mail:iclalhocanli2163@gmail.com

Posta kodu: 63000

Tlf:0414 3444092

Geliş tarihi / Received:

30.09.2019

Kabul tarihi / Accepted: 05.11.2019

\section{DOI: 10.35440/hutfd.625999}

Bu makale, Türk Toraks Derneğinin uluslararası katılımlı 22. yıllık kongresi, 10-14 nisan 2019 / Antalya'da Sözlü Sunum olarak kabul edildi. 


\section{Giriş}

Bronşektazi, hava yolu çapı ayrımı gözetmeksizin tüm bronş ağacını tutabilen, bronş duvarlarının elastik ve kas bileşenlerinin yıkımı sonucu bronşların anormal ve irreversibl dilatasyonu ile karakterize süpüratif bir akciğer hastalığıdır. Bronşektazi tanısı kesin olarak bronkografi ile konulmakla birlikte; günümüzde bu konvansiyonel yöntem artık kullanılmamakta olup, bunun yerini altın standart olarak yüksek rezolüsyonlu bilgisayar tomografisi (YRBT) almıştır (1). Bronşektazinin oluşmasında ve gelişip ilerlemesinde majör neden enfeksiyon olduğu için, bu hastaların tedavisinin temelini enfeksiyon yükünün azaltılması oluşturur $(2,3)$.

Akut bronşektazi alevlenmelerinin en büyük nedeni tekrarlayan enfeksiyonlar ve mukosiliyerklirensin bozulmasıyla oluşan bakteriyel kolonizasyondur. Bu alevlenmelere bağlı olarak, hastaların hastaneye yatış sayıları ve hastanede kalış süreleri de artmaktadır. Bu nedenle, akut bronşektazi alevlenmelerinin tedavisinde antibiyotikler sıklıkla kullanıı (4). Antibiyotik seçimi ampirik olarak yapılabileceği gibi, başta balgam olmak üzere diğer vücut sıvılarından yapılacak mikrobiyolojik inceleme sonuçlarına göre de yapılabilir $(5,6)$. Dolayısıyla balgam kültürü, bronşektazili hastaların havayolu florasının izlenmesi ve spesifik tedavi gerektiren mikroorganizmaların belirlenmesi için hem tanı hem de takipte önem kazanmaktadır.

Retrospektif olarak yaptıgımız bu çalışmada, kliniğimizde bronşektazi tanısıyla takip edilmiş hastaların balgam kültür sonuçlarını ve bunun hastanede kalış süresine etkisini araştırdık.

\section{Materyal ve Metot}

Çalışmamıza Ocak 2018-Aralık 2018 tarihleri arasında Harran Üniversitesi Tıp Fakültesi göğüs hastalıkları kliniğinde bronşektazi tanısyla takip edilen 23 hasta geriye dönük olarak dahil edildi. Bronşiektazi tanısının konması, YRBT ile yapıldı. Belirtilen tarihler arasında YRBT ile bronşektazi tanısı alan, bronkoalveolar lavaj (BAL), balgam ve asidorezistan basil (ARB) yayma sonucu olan ve 18 yaş üstü olan tüm hastalar çalışmaya dahil edildi. 18 yaş altı, YRBT yada Toraks bilgisayar tomografi (BT) sonucu olmayan ve balgam/BAL kültür sonucu olmayan hastalar çalışma dışı bırakıldı. Çalışmaya dahil edilen tüm hastaların laboratuvar, balgam ve radyolojik verileri retrospektif olarak incelendi.

Laboratuvar tetkikleri olarak; hastaların yatışının 1.günü alınan hemogram, C-reaktif protein (CRP) ve biyokimyasal kan tetkikleri incelendi. Radyolojik tetkik olarak ise; tüm hastaların YRBT'leri incelendi. YRBT' ye göre bronşial genişleme hafif ve bronş konturları düzgün olanlar silindirik bronşektazi, bronşial genişleme orta şiddette ve bronş konturları tesbih şeklinde düzensiz olanlar variköz bronşektazi ve bronş lümenleri $1 \mathrm{~cm}$ 'den geniş olup bronşları balon şeklinde olanlar ise kistik bronşektazi olarak sınıflandırıldı (7). Balgam çıkaran hastaların, yatışının 1. günü balgam gram boyama, nonspesifik balgam kültürü ve ARB çalışııması için balgam numuneleri alındı. Balgam çıkaramayan hastalardan ise, onam alınarak fiberoptik bronkoskopi yapıldı ve BAL alındı. Bu sıvının kültür ve ARB sonuçları değerlendirildi.

Bronşektazi tanısı alan tüm hastalara, yatışının 1.günü ampirik tedavi başlanmıştı. Ardından takiplerde kültür ve antibiogram sonuçlarına göre hastaların antibiotik revizyonu yapılmıştı. Tüm hastaların demografik özellikleri, hastanede kalış süreleri, kullandıkları antibiyotikler ve kültür sonucuna göre yapılan antibiyotik değişimleri kaydedildi. Çalışmamız için Harran Üniversitesi Tıp Fakültesi etik kurulundan onay alındı.

\section{İstatiksel analiz}

Verilerin istatistiksel analizinde SPSS 22.0 programı kullanıldı. İncelenen değişkenlerin normal dağılıma uyup uymadığı Shapiro-Wilk testi ile değerlendirildi. Normal dağılıma uyan sürekli değişkenler ortalama \pm standart sapma ile ifade edildi ve Student $t$ testi ile karşılaştırıldı. Normal dağılıma uymayan sürekli değişkenler ortanca (25-75. çeyreklikler) olarak ifade edildi ve Mann-Whitney U testi ile karşılaştırıldı. Kategorik değişkenler ise yüzde olarak ifade edildi ve ki-kare testi ile karşılaş̧ıııldı. 2'den fazla grubun karşılaştırıması için Kruskal-Wallis testi uygulandı. Korelasyon analizleri için Spearman korelasyon katsayısı kullanıldı. P değerinin 0.05 'in altında olması istatistiksel anlamlılık olarak kabul edildi.

\section{Bulgular}

Çalışmamızda 10'u erkek, 13'ü kadın olmak üzere toplam 23 hasta değerlendirildi. Hastaların ortanca yaş değeri 55 (32-63) yıl idi. Komorbid durum olarak; dört hastada astım, bir hastada Kartagener sendromu mevcuttu. Radyolojik görünümlere bakıldığında; 15 hastada kistik, 4 hastada silindirik ve 4 hastada da varriköz patern görülmekteydi. 14 hastanın kültüründe üreme saptanmazken, 9 hastanın ise kültüründe üreme saptandı. Kültürde üreyen etkenlere bakıldığında; 4 hastada Pseuodomonas aeruginosa, 4 hastada Klebsiella Pnömoni ve 1 hastada Mycobacterium Tuberculosis üremesi olduğu görüldü. 5 hastada $(\% 21.7) \geq 2$ hastane yatış mevcuttu. $\geq 2$ hastane yatışı olan hastaların kültür sonucuna bakıldığındaysa; 3 hastanın kültüründe Pseuodomonas aeruginosa ve 1 hastanın kültüründe Klebsiella Pnömoni ürediği, 1 hastada ise kültürde üreme olmadığı tespit edildi (Tablo 1).

Çalışma gurubumuz, kültürde üreme olanlar (9 hasta) ve kültürde üreme olmayanlar (14 hasta) şeklinde 2 gruba bölündü. Her iki grup, enfeksiyon belirteçleri ve hastanede yatış süresi açısından karşılaştıııldı. Kültürde üreme olan hastalar ile kültürde üreme olmayan hastalar arasında CRP [2.8 (0.7-4.8)'e karşın 3.9 (1.2-7.9), $p=0.404$ ] ve lökosit [10.9 (6.9-12.8)'e karşın 9.7 (8.3-12.6), $p=0.850$ ] düzeyleri açısından anlamlı bir farklılık tespit edilmedi 
(Tablo 2). Ek olarak, kültürde üreme olmayan hastalar ile karşılaştırıldığında, kültürde üremesi olan hastalarda hastane yatış süresi daha uzun olmakla beraber bu farklıIık istatistiksel açıdan anlamlı bir düzeyde değildi (10.1 \pm 5.1 gün'e karşın $7.8 \pm 5.5$ gün, $p=0.135$ ) (Şekil 1 ).

\begin{tabular}{ll}
\multicolumn{2}{l}{ Tablo 1. Hastaların genel karakteristik ve laboratuvar özellikleri } \\
\hline Değişkenler & (n=23) \\
\hline Yaş (yll) & $55(32-63)$ \\
Cinsiyet, Erkek (\%) & $10(43.5)$ \\
Komorbiditeler & \\
\hline Astım & $4(17.4)$ \\
Kartagener sendromu & $1(4.3)$ \\
Radyolojik görünüm & $15(65.2)$ \\
\hline Kistik & $4(17.4)$ \\
Varriköz & $4(17.4)$ \\
Silindirik & $5(21.7)$ \\
Glikoz (mg/dat) & $116(94-140)$ \\
Kreatinin (mg/dl) & $07(0.6-0.7)$ \\
Lökosit (e3/uL) & $9.8(7.9-13.7)$ \\
C-reaktif protein (mg/dl) & $3.4(1.1-6.7)$ \\
Albumin (g/dL) & $3.6(2.8-3.8)$ \\
Eozinofil (e3/uL) & $0.1(0.05-0.33)$ \\
Bazofil (e3/uL) & $0.07(0.04-0.1)$ \\
Hemoglobin (g/dL) & $12.5(10.9-13.2)$ \\
Platelet (e3/uL) & $304(266-368)$ \\
Külür sonucu & \\
\hline Normal flora & $14(60.9)$ \\
Psuodomonas Aeriguginosa & $4(17.4)$ \\
Klebsiella Pnömoni & $4(17.4)$ \\
Mycobacterium Tuberculosis & $1(4.3)$ \\
\hline
\end{tabular}

Tablo 2. Kültürde üreme saptanan ve saptanmayan hastaların enfeksiyon belirteçlerinin karşılaştırılması

\begin{tabular}{llll}
\hline & $\begin{array}{l}\text { Üreme }(+) \\
(n=9)\end{array}$ & $\begin{array}{l}\text { Üreme }(-) \\
(n=14)\end{array}$ & $P$ \\
\hline Lökosit & $10.9(6.9-12.8)$ & $9.7(8.3-12.6)$ & 0.850 \\
C-reaktif protein & $2.8(0.7-4.8)$ & $3.9(1.2-7.9)$ & 0.404 \\
\hline
\end{tabular}

Kültürde üreme olan hastaların, üreyen etkene göre hastanede yatış sürelerinin karşıllaştırıması Tablo 3'te gösterilmektedir. Mycobacterium tuberculosis sadece 1 hastada ürediği için, analizlerin daha sağlıklı olması amacıyla bu hasta analize dâhil edilmedi. Geri kalan etkenlere bakıldığında, P.aeruginosa üremesi olan hastalarda hastanede yatış süresi 14 (12-16.7) gün, K. pnomonia üremesi olan hastalarda hastanede yatış süresi 8 (2.7-11) gün ve üreme olmayan hastalarda hastanede yatış süresi 7 (3.7-8.5) gün idi. P.aeruginosa üremesi olan hastalarda hastanede yatış süresi anlamlı olarak daha uzun idi $(p=$ 0.034).

\section{Tartışma}

Çalışmamızda bronşektazi tanısıyla takip edilmiş hastaların balgam kültür sonuçlarını ve bunun hastanede kalış süresine etkisini araştırdık. Çalışmamızın ana bulgusu, kültürde P.aeruginosa üremesi olan bronşektazili hastalarda hastane yatış süresinin anlamlı olarak daha uzun olduğudur.

Tablo 3. Kültür (+) hastaların, hastane yatış sürelerinin karşılaştırılması

\begin{tabular}{lllll}
\hline & $\begin{array}{l}\text { P.aeruginosa } \\
\text { üreyenler } \\
(n=4)\end{array}$ & $\begin{array}{l}\text { K.pnomonia } \\
\text { üreyenler } \\
(n=4)\end{array}$ & $\begin{array}{l}\text { Üreme olmayanlar } \\
(n=14)\end{array}$ & $P$ \\
\hline $\begin{array}{l}\text { Yatış süresi } \\
\text { (gün) }\end{array}$ & 14 (12-16.7) & $8(2.7-11)$ & $7(3.7-8.5)$ & 0.034 \\
\hline
\end{tabular}

Bronşektazi, bir yada daha fazla bronşun anormal dilatasyonu ile karakterize, öksürük ve bol miktarda balgamın eşlik ettiği, kalıcı ve kronik havayolu hastalığıdır. Sıklıkla altta yatan kronik obstrüktif akciğer hastalığı (KOAH), Kartagener sendromu, çocukluk çağında geçirilmiş enfeksiyonlar, yabancı cisim aspirasyonu, malignite gibi çeşitli etyolojik faktörler nedeniyle gelişmektedir $(5,8,9)$. Kömüs ve ark. nın yapmış oldukları çalışmada, 63 bronşektazi tanılı hastanın 34'ünde KOAH tanısı olduğu saptanmıştır (10). Yapılan çalışmalarda popülâsyonlar arasında farkılık göstermekle birlikte, özellikle orta-ağır KOAH'ı hastalarda oldukça yüksek oranlarda $(\% 28-57,6)$ bronşektazi bulunurken (11-13), başka bir çalışmada ise bronşektazi hastaların yaklaşık \%68 'inden astım birlikteliği olduğu saptanmıştır (14). Çalışmamızda, bronşektazi tanısı almış 23 hastanın dördünde astım tanısı vardı, birinde ise yaklaşık bir yıl önce tanı konmuş kartagener sendromu mevcuttu. Ancak, çalışmamızda hiçbir hastada KOAH saptanmadı. Bu durum, çalışmamızdaki hasta sayısının az olması ile açıklanabilir.

Bronşektazi tanılı hastaların \%64-\%79'unda, hava yollarında kalıcı bakteriyel enfeksiyon olduğunu kanıtlamıştır $(5,6)$. Pseudomonas aeruginosa ve Hemophilus influenza dünya genelinde bronşektazili hastalarda havayollarında en sık rastlanan bakterilerdir, ancak oranları popülasyonlar arasında farklııı göstermektedir $(15,16)$. Bronşektazili hastalarda, hava yollarında saptanan diğer bakteri türleri arasında Streptococcus, Prevotella, Veillonella ve Staphylococcus bulunur (17-19). Yapılan çalışmalarda da, bronşektazik alevlenmelerde en sık saptanan mikroorganizmaların Hemophilus influenzae, Pseudomonas aeruginosa ve görece daha düşük oranlarda Streptococcus pneumoniae, Moraxella catarrhalis ve Staphylococcus aureus olduğu gözlenmiştir $(7,14,20,21)$. Ek olarak, az bir kısım hastada ise (\%1-2) tüberküloz dışı mikobakteri (TDM) enfeksiyonlarının gelişebildiği belirtilmektedir (22). Bizim çalışmamızda, 1 hastanın balgam kültüründe mycobacterium tuberculosisürerken , 4 hastanın kültüründe klebsiella pneumonia ve yine 4 hastanın kültüründe pseudomonas aeruginosa üremişti. Bronşektazik hastaların mukosiliyer klirensi bozuldugundan bronşlarda oluşan inflamasyon ve hasar nedeniyle akut ataklar ve buna bağlı hastane yatışları gerekebilir. 


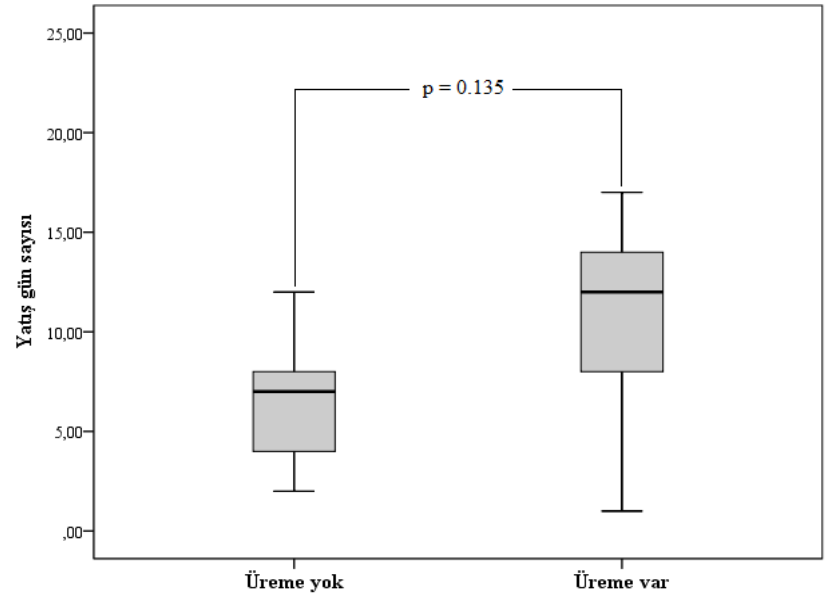

Şekil 1.Kültür sonuçları ile hastane yatış süresi karşılaştırıması

Gözlemsel çalışmaların sistematik incelenmesinde $P$. aeruginosa enfeksiyonunun mortalite riskinde üç kat artı̧, hastaneye yatış riskinde yaklaşık yedi kat artış ve her yıl ortalama en az bir alevlenme ile ilişkili olduğunu belirlenmiştir (24). Pseudomonas ve $\mathrm{H}$. influenza olgularının karşılaştırıldığında farklı bir çalışmada ise, Pseudomonas'lı olguların yaşam kalitelerinin daha düşük, hastane yatış sayılarının daha fazla olduğu saptanmıştır (24). Yine başka bir çalışmada Pseudomonas üreyen hastaların daha sık atak geçirdiği ve hastanede daha uzun süre yattığı gözlenmiş̧tir (25). Bu çalışmaya benzer şekilde, bizim çalışmamızda da kültürde Pseudomonas aeruginosa üremesi olan hastaların hastanede yatış süreleri anlamlı olarak daha uzun idi. Ek olarak, $\geq 2$ hastane yatış öyküsü olan 5 hastanın da 3'ünde Pseudomonas aeruginosa üremesinin mevcut olduğu saptandı. Bu bulgular kültürde Pseudomonas aeruginosa üremesi olan hastalarda hastane yatışının daha uzun olduğunu ve bu hastaların daha kötü prognoza sahip olduklarını göstermektedir.

Yapılan çalışmalarda, etkene yönelik antibiyotik kullanımının bronşektazili olgularda yıllık atak sayısını, hastaneye yatış sıklığını ve hastane yatış süresini azaltırken, hayat kalitesi ve solunum fonksiyonlarını arttırdığı gözlenmiştir $(26,27)$. Bu nedenle bronşektazi tanılı hastaların, hastane yatışlarında balgam kültürleri alınması ve kültür sonuçlarına göre uygun antibioterapi verilmesi önerilmektedir. Ayrıca, koruyucu önlemler alınarak (influenzapnömokok aşıları, uzun süreli antibioterapi) hem enfeksiyon ve kolonizasyon oranları, hem de hastaneye başvuru sıkığı ve hastane yatış süreleri azaltılıp hastanın yaşam kalitesi arttırılabilir.

Çalışmamızın en büyük kısıt|ıığı hasta sayısının az olmasıdır. Ancak, buna rağmen elde ettiğimiz veriler mevcut literatür sonuçları ile benzerdir. Ek olarak, kültür üremesinin hastaların taburcu olduktan sonraki yaşam kalitesi ve uzun dönem sonuçları üzerindeki etkisinin incelenmesi de çalışmamıza ek katkı sağlayabilirdi. Bu konuda daha anlamlı veriler elde etmek ve mevcut literatür bilgilerine katkı sağlamak için hasta sayısının daha yoğun olduğu ileri dönük çalışmalara intiyaç olduğunu düşünmekteyiz.

\section{Kaynaklar}

1. Bruggen-Bogaarts $B$, Bruggen $H$, Waes $P$, Lammer JW. Screening for bronchiectasis. A comparative study between chest radiography and high-resolution CT. Chest. 1996; 109(3): 608-711.

2. Ooi GC, Khong PL, Chan-Yeung M, Ho JC, Chan PK, Lee JC, et al. Highresolution $\mathrm{CT}$ quantification of bronchiectasis: Clinical and functional correlation. Radiology. 2002; 225(3): 663-72

3. Zoumot Z, Wilson R. Respiratory infection in non cystic fibrosis bronchiectasis. Curr Opin Infect Dis. 2010;23:165-70

4. Pasteur MC, Bilton D, Hill AT. British Thoracic Society guideline for non-CF bronchiectasis. Thorax. 2010;65 (Suppl 1):i1-i58

5. Angrill J, Agusti C, Torres A. Bronchiectasis. Curr Opin Infect Dis. 2001;14(2):1937

6. King PT, Holdsworth SR, Freezer NJ, Villanueva E, Holmes PW. Microbiologic follow-up study in adult bronchiectasis. Respir Med. 2007;101(8):1633-8.

7. Hartman TE, Primack SL, Lee KS, Swensen SJ, Müller NL. CT of bronchial and bronchiolar diseases. Radiographics.1994;14:991-1003.

8. Fishman AP. Bronchiectasis. In: Fishman AP, Elias JA, Fishman JA, et al (eds). Fishman's Pulmonary Diseases and Disorders. 3rd ed. Vol 2. International Edition: McGraw-Hill, 1998: 2045-69.

9. Barker A. Bronchiectasis. N Engl J Med. 2002;346(18):1383-93.

10. N Kömüs, KC Tertemiz, A Akkoçlu, Z Gülay, E Yılmaz. Pseudomonas aeruginosa colonisation in bronchiectatic patients and clinical reflections. Tüberküloz ve Toraks Dergisi. 2006; 54(4): 355-362.

11. Martinez-Garcia MA, Soler-Cataluna JJ, Donat Sanz Y, Catalan Serra P, Agramunt Lerma M, Ballestin Vicente J, et al. Factors associated with bronchiectasis in patients with COPD. Chest. 2011;140(5):1130-1137.

12. Martinez-Garcia MA, de la Rosa D, Soler-Cataluna JJ, Donat-Sanz Y, Catalan Serra P, Agramunt Lerma M, et al. Prognostic Value of Bronchiectasis in Patients with Moderate-to-Severe Chronic Obstructive Pulmonary Disease. Am J Respir Crit Care Med. 2013 15:187(8):823-31.

13. Patel IS, Vlahos I, Wilkinson TM, Lloyd-Owen SJ, Donaldson GC, Wilks M, et al. Bronchiectasis, exacerbation indices and inflammation in chronic obstructive pulmonary disease. Am J Respir Crit Care Med. 2004;170(4):400-7.

14. Mäntylä J, Mazur W, Törölä T, Bergman $P$, Saarinen T, Kauppi P. Asthma as aetiology of bronchiectasis in Finland. Respir Med. 2019;152:105-11.

15. Dimakou K, Triantafillidou C, Toumbis M, Tsikritsaki K, Malagari K, Bakakos $P$. Non CF-bronchiectasis: Aetiologic approach, clinical, radiological, microbiological and functional profile in 277 patients. Respir Med. 2016;116:1-7.

16. Borekci S, Halis AN, Aygun G, Musellim B. Bacterial colonization and associated factors in patients with bronchiectasis. Ann Thorac Med. 2016; 11(1):55-9.

17. Duff RM, Simmonds NJ, Davies JC, Wilson R, Alton EW, Pantelidis P, et al. A molecular comparison of microbia Icommunities in bronchiectasis and cystic fibrosis. Eur Respir J. 2013:41(4):991-993.

18. Rogers GB, van der Gast CJ, Cuthbertson L, Thomson SK, Bruce KD, Martin $\mathrm{ML}$, et al. Clinical measures of disease in adult non-CF bronchiectasis correlate with airway microbiota composition. Thorax. 2013;68(8):731-737

19. Cox MJ, Turek EM, Hennessy C, Mirza GK, James PL, Coleman M, et al. Longitudinal assessment of sputum microbiome by sequencing of the 16S rRNA gene in non-cystic fibrosis bronchiectasis patients. PLoSOne. 2017;12(2):e0170622.

20. Zaid AA, Elnazir B, Grealy P. A decade of non-cystic fibrosis bronchiectasis. Ir Med J. 2010;103:77-9.

21. McFarlane J, McAlinden $P$, de Soyza A. Longitudinal study of sputum microbiology in adult non-CF bronchiectasis. Thorax. 2010;65 (suppl. 4): A177-8.

22. Fowler SJ, French J, Screaton NJ, Foweraker J, Condliffe A, Haworth CS, et al. Non tuberculous mycobacteria in bronchiectasis: prevalence and patient characteristics. Eur Respir J. 2006;28:1204-10.

23. Finch S, McDonnell MJ, Abo-Leyah $\mathrm{H}$, Aliberti S, Chalmers JD. A comprehensive analysis of the impact of Pseudomonas aeruginosa colonization on prognosis in adult bronchiectasis. Ann Am Thorac Soc. 2015; 12: 1602-11.

24. Wilson CB, Jones PW, O'Leary CJ, Hansell DM, Cole PJ, Wilson R. Effect of sputum bacteriology on the quality of life of patients with bronchiectasis. Eur Respir J. 1997;10(8):1754-6

25. Rogers GB, Zain NM, Bruce KD, Burr LD, Chen AC, Rivett DW, et al. A novel microbiota stratification system predicts future exacerbations in bronchiectasis. Ann Am Thorac Soc. 2014;11(4):496-503.

26. Evans DJ, Bara Al, Greenstone M. Prolonged antibiotics for purulent bronchiectasis in children and adults. Cochrane Database Syst Rev. 2007;18 (2)

27. Cymbala AA, Edmonds LC, Bauer MA, Jederlinic PJ, May JJ, Victory JM, et al. The disease modifying effects of twice weekly oral azithromycin in patients with bronchiectasis. Treat Respir Med. 2005;4(2):117-22. 